\title{
SYSTEMS ENGINEERING BELIEFS: CONTEMPLATING PERSONAL PERCEPTIONS REGARDING STATE OF THE ART
}

\author{
B.E. WHITE \\ Complexity Are Us $\leftarrow$ Systems Engineering Strategies, USA.
}

\begin{abstract}
Systems engineering (SE) theories and practices for effectively dealing with complex systems are still evolving. Principal stakeholders are integral to complex systems, so we cannot predict or prespecify how the system changes. Every systems engineer has his own professional viewpoint derived from cultural background, upbringing/education and experience/maturation. The author has decided how all this fits his career and current 'mindsight'. He encourages other systems' engineers to examine and share their thoughts to help attain a more collective and forward looking view of systems engineering to advance the field. This paper provides a framework for system engineers to contemplate whether they are of the traditional system of systems; enterprise; or the complex type. Perspectives on SE attributes are offered to assist any systems engineer in characterizing his belief system, stylistic approach, and overall effectiveness in engineering complex systems. Systems engineers might reflect on what applies to them and to what relative extent. If a particular set of attributes dominates, is that appropriate? What changes in outlook, style, and emphasis might make a more effective systems engineer? Several existence categories are suggested and proportioned through each of life's stages. System engineers may contemplate how these trends have affected their past behaviors, and how possible re-directions might improve their future accomplishments. Thinking through what we have done, are doing, and want to do as systems' engineers is recommended. Anyone's chosen way is no better than any other possibility. It depends on a multitude of circumstances in each of our lives.

Keywords: belief system, complex system, enterprise, religion, system of systems, systems engineering.
\end{abstract}

\section{INTRODUCTION}

Many systems' engineers practice the art of systems engineering (SE) following their own belief system with respect to the spectrum of SE methods of which they are aware or might contemplate applying. Since this is analogous to one's religious beliefs, some parallels are drawn between religion's belief systems, viz., Theism, Agnosticism, and Atheism, and (classical, conventional, or traditional) SE, System of Systems (SoS) Engineering (SoSE), Enterprise SE (ESE), and Complex Systems Engineering (CSE) [1]. A system engineer's existential categories, viz., authorities, exposure, learning, paths, and contributions, are also discussed as lifetime threads that influence SE.

It is extremely difficult, if not impossible, to provide theoretical or experimental evidence that the opinions expressed herein are valid. Instead, without any so-called proofs, a dialog involving fictitious characters is used to provide balanced views. Most readers will find this interesting and somewhat entertaining. The principal goal is to stimulate reflection and creative thinking about improving SE approaches to our most difficult problems. Unfortunately, too many systems' engineers set their sights much lower and are content to immerse themselves in more limited situations.

Table 1 summarizes the cast of characters. Each statement will be preceded by the maker's character name to better flag the point of view espoused.

\section{SYSTEMS ENGINEERING ATTRIBUTES}

Facilitator: Thank you for agreeing to meet. We can all benefit from discussing our belief systems and from where they derived in improving our SE practice. The profession needs to better handle not only your individual and organization's needs but also the world's more pressing problems. Let's 
Table 1: Cast of characters in dialog.

\begin{tabular}{|c|c|c|}
\hline $\begin{array}{l}\text { Character } \\
\text { name }\end{array}$ & Character type & Role in dialogue \\
\hline Agnostic & Ambivalent about God & Humble in not being sure what to believe \\
\hline Atheist & Does not believe in gods of any kind & $\begin{array}{l}\text { Favors rationale thought; beliefs must } \\
\text { make sense logically }\end{array}$ \\
\hline Boss & $\begin{array}{l}\text { Autocratic but loyal to and defender } \\
\text { from outsiders of people in organization }\end{array}$ & $\begin{array}{l}\text { Advocate of hierarchical organizational } \\
\text { structure and pleasing those at the top }\end{array}$ \\
\hline Coach & $\begin{array}{l}\text { Believer in positively shaping personal } \\
\text { character through competitive sports }\end{array}$ & $\begin{array}{l}\text { Shows analogies between lessons of life } \\
\text { and good systems engineering }\end{array}$ \\
\hline $\begin{array}{l}\text { Complex } \\
\text { Systems } \\
\text { Engineer }\end{array}$ & $\begin{array}{l}\text { Focused on the most general form of } \\
\text { systems engineering and advising on } \\
\text { techniques that might be more effective }\end{array}$ & $\begin{array}{l}\text { Emphasizes complex systems behav- } \\
\text { iors and complex systems engineering } \\
\text { principles }\end{array}$ \\
\hline $\begin{array}{c}\text { Conservative } \\
\text { Advocate }\end{array}$ & $\begin{array}{l}\text { Believes in individual freedom, right to } \\
\text { life, and limited government }\end{array}$ & $\begin{array}{l}\text { Straight-forward, into discipline, and } \\
\text { proud of being a Chris tian }\end{array}$ \\
\hline $\begin{array}{l}\text { Enterprise } \\
\text { Systems } \\
\text { Engineer }\end{array}$ & $\begin{array}{l}\text { Takes broad viewpoint embracing } \\
\text { homeostatic systems not necessarily } \\
\text { containing only component systems }\end{array}$ & $\begin{array}{l}\text { Eager to learn more about what complex } \\
\text { systems engineering techniques might be } \\
\text { more effective }\end{array}$ \\
\hline Facilitator & $\begin{array}{l}\text { Concerned with fundamental issues, } \\
\text { abstract ideas, and significant progress } \\
\text { toward solving human made problems }\end{array}$ & $\begin{array}{l}\text { Leads in trying to stimulate dialogue that } \\
\text { may help systems engineers appreciate } \\
\text { how belief systems shape approaches to } \\
\text { the profession }\end{array}$ \\
\hline Follower & $\begin{array}{l}\text { Reads lots of advanced systems engi- } \\
\text { neering papers and as ks for more }\end{array}$ & $\begin{array}{l}\text { Encourages further pursuit of effective } \\
\text { complex sys tems engineering methods }\end{array}$ \\
\hline $\begin{array}{l}\text { Liberal } \\
\quad \text { Supporter }\end{array}$ & $\begin{array}{l}\text { Concerned with human welfare and } \\
\text { favoring government action }\end{array}$ & Voice of compassion \\
\hline Lover & $\begin{array}{l}\text { Attracted to kind, well-rounded, hard- } \\
\text { working intellectuals who can als o play }\end{array}$ & $\begin{array}{l}\text { Reminds friends that a balanced life is } \\
\text { more important than workaholic pursuits }\end{array}$ \\
\hline Parent & $\begin{array}{l}\text { Loves and cares for their kids but leaves } \\
\text { a lot up to school teachers }\end{array}$ & $\begin{array}{l}\text { Defensive, recognizing only limited } \\
\text { responsibility for rearing children }\end{array}$ \\
\hline $\begin{array}{l}\text { School } \\
\quad \text { Teacher }\end{array}$ & $\begin{array}{l}\text { Remembered as favorite of many stu- } \\
\text { dents even much later in life }\end{array}$ & $\begin{array}{l}\text { Endures as tremendous influence in atti- } \\
\text { tudes about life and career development }\end{array}$ \\
\hline $\begin{array}{l}\text { System of } \\
\text { Systems } \\
\text { Engineer }\end{array}$ & $\begin{array}{l}\text { Unders tands increas ed difficulty in engi- } \\
\text { neering complicated and more complex } \\
\text { systems containing component systems }\end{array}$ & $\begin{array}{l}\text { Largely oriented toward military systems } \\
\text { of systems characteristic of principal U.S } \\
\text { Department of Defense concerns }\end{array}$ \\
\hline $\begin{array}{l}\text { Systems } \\
\text { Engineer }\end{array}$ & $\begin{array}{l}\text { Classical, conventional, or traditional } \\
\text { systems engineering practitioner }\end{array}$ & $\begin{array}{l}\text { Defends conventional systems engineer- } \\
\text { ing methods and is very reluctant to } \\
\text { change his/her prevailing mindset }\end{array}$ \\
\hline $\begin{array}{l}\text { Systems } \\
\text { Thinker }\end{array}$ & $\begin{array}{l}\text { Knowledgeable about complex systems, } \\
\text { enterprises, systems of systems, and } \\
\text { systems; smart, and dispassionate }\end{array}$ & $\begin{array}{l}\text { Provider of balanced and objective view- } \\
\text { points and ideas for achieving deeper } \\
\text { research and more effective practices }\end{array}$ \\
\hline Theist & Believes in God & Accepts religious beliefs primarily on faith \\
\hline
\end{tabular}


first focus on religious belief systems. Other topics will naturally follow. Who will begin the discussion?

\subsection{Religious belief systems}

Theist: All right, I'll start. Theism is the most common religious belief system. According to the Encarta Dictionary: theism has two meanings: (1) Belief in God, i.e. belief that one God created and rules humans in the world and (2) belief in God or Gods. Theists believe God exists and have, in effect, adopted pantheism: (1) belief that God is everything and (2) belief in all deities. I characterize the religious philosophy of theists and pantheists by tradition, acceptance, devotion, faith, dogma, and ritual, and strongly support these tenets.

Agnostic: Agnosticism is much less common. Encarta says agnostics view God's existence as unprovable. Agnostics are neutral about God's existence and have effectively adopted religious naturalism [2]: (1) Relating to (belief in, teaching or practice of) religion and (2) believing in a higher being. Religious naturalism seems to fall between agnosticism and theism. I characterize agnostics by humility, ambivalence, uncertainty, openness, learning, and analysis.

Atheist: Atheism is the rarest. Atheists do not believe in a personal God or any gods at all. We are characterized by rationality, skepticism, humanism, experimentation, study, and synthesis. In my experience, most people feel that atheism is not a religious belief. However, in the sense of being 'a belief or practice forming part of someone's thought about 1/4 a divine being' (Oxford American College Dictionary), it really is!

Conservative advocate: Christianity is the true religion, as evidenced by Jesus's good works, his resurrection, and the profound impact belief in Jesus Christ has had on the world. I support the view of theists.

Liberal Supporter: Being a Unitarian Universalist, all three views have merit. Why can't we respect anyone's belief system? The world should share beliefs openly, subjugate harsh judgments, and embrace uplifting ideas.

Systems Thinker: This is a reasonable beginning, and I commend the Facilitator for instigating this meeting.

Facilitator: I think so, too, and thank you. Next let's pose typical attributes associated with different kinds of SE and relate those attributes to belief systems.

\subsection{SE attributes}

Systems engineer: Attributes associated with theists are risks, reductionism, technology, requirements, and doctrine. SE is structured, ordered, predictable, and malleable. Complicated problems can be effectively addressed provided sufficient care is taken. Requirements can be clearly, unambiguously, and promptly defined by the user, the customer, and the SE team. Problems can be subdivided, optimizing each piece separately, to be reassembled without perturbing the collective effect. The latest technology is applied to the extent possible. Risks needing mitigation are recognized and handled. A very logical lifecycle process is followed.

Complex systems engineer: Allow me to take issue with a few of your points. In your more complex problems, haven't you noticed how difficult it is for anyone to define unchanging requirements? Reductionism doesn't work because by the time you apply your rigid, linear, lifecycle process, the system and its environment has evolved.

Enterprise systems engineer: Right, a broader approach must be taken, especially in enterprises that are more general than regular systems or more complex than SoS's. I want to learn about more effective SE techniques. 
System of systems engineer: SE is just fine! It just needs to be extended to accommodate collections of systems. The U.S. Department of Defense (DoD) recognized this long ago, and mounted extensive efforts to concentrate on the most important area, SoS's and SoSE.

Enterprise systems engineer: SE attributes associated with agnostics are independence, innovation, networking, and science. Agnostics view SE as more complex and challenging. There is more independence of thought, innovation in trying new solutions, networking with colleagues to share information, and the application of scientific facts, at least until disproven.

Complex systems engineer: SE attributes associated with atheists are isolation, distrust, contemplation, and outreach. Atheists view SE as very complex, much more than just complicated. They tend to: be ostracized, particularly if abrasive; often express minority opinions or resist management; distrust conventional methods of treating difficult problems; continually look for more effective pathways; be thoughtful and examine situations with multiple perspectives; look for factbased evidence in others' work that might support their own notions or give them ideas; and interact with their receptive and intellectually stimulating colleagues.

System of systems engineer: SE atheists reap what they deserve! Why don't they contribute something useful to the program instead of causing disruption?

Systems engineer: I agree. What we do works well enough. Do not judge us!

Facilitator: Actually, I think we've all wrestled with most of these thoughts, and please, let's concentrate on evaluating and sharing comments on the ideas expressed, and neither insult nor question the integrity of the speaker.

\subsection{SoSE attributes}

System of systems engineer: SoSE attributes associated with theists are modularity, security, hierarchy, and hubris. Theists view SoSE as an extension of SE. Their tendency is to continue trying traditional SE techniques. Here, they run into difficulty because an SoS is a collection of independent systems whose interactions can be much more involved. This leads theists to emphasize modularity, a good organizing principle. Theists are concerned with security to counter lack of trust. Hierarchy takes a larger role because an SoS rides above its component systems, and processes are driven by authorities with a top-down point-of-view. Theists exhibit hubris in their comfort with SE methods.

Enterprise systems engineer: I agree and suggest that SoSE attributes associated with agnostics are POET (Political, Operational, Economic, and Technological [factors]), discussions, heuristics, and layering. There is less hubris compared to theists because agnostics better appreciate the difficulties involved. They share perspectives in understanding SoS's; look for rules-of-thumb to improve decision-making; and bypass modularity to advocate a more effective layered architecture.

Complex systems engineer: Very well said. SoSE attributes associated with atheists include opportunities, capabilities, interoperability, and systems thinking. Atheists know that opportunities abound and can lead to better solutions. They: are not wedded to requirements but are interested in increasing capabilities; value interoperability, not only within a SoS but also across SoS's; and employ systems thinking, including what has been omitted and what might not even be there - that should be.

Systems thinker: Glad you mentioned my realm. Holistic thinking is critical, not only in your CSE but also in ESE, SoSE, and where it is most lacking, SE.

Systems engineer: I'm not sure what holistic means but I think you're being unfair to our practice. If we take care of the parts, the whole takes care of itself!

Facilitator: Again, let's all be more careful how we treat each other. 


\subsection{ESE/CSE attributes}

Complex systems engineer: ESE/CSE attributes associated with theists include complication, optimization, point-to-point, and dicta. Theists: use the word complex when they mean complicated; discount complexity theory; try to optimize a CS instead of balancing competing interests to achieve results that satisfies principal stakeholders; gravitate to point-to-point communications which is not scalable in a large network, there being too many combinations to detail and update; and are not interested in studying complexity, CSs, or ESE/CSE techniques but readily embrace dicta on what higher authorities think works.

Systems engineer: Didn't you hear the Facilitator just now? Your presentation style is brutal! Nonetheless, I think I understand most of what you say and will consider your remarks carefully, although maybe later with my own team.

Enterprise systems engineer: ESE/CSE attributes associated with agnosticism include humility, balance, interactions, and simplicity. Agnostics: view ESE/CSE with respect; bring humility to the study and contemplation of, and attempted interventions in, a CS; are more inclined to try to achieve balance among competing thrusts; recognize the importance of understanding interactions among CS portions that strongly affect overall behavior; and try to penetrate through complexity to reach simplicity. Perhaps we need more agnosticism in all of us!

Complex systems engineer: ESE/CSE attributes associated with atheists include holism, transdisciplines, trust, and self-organization. Atheists: view ESE/CSE with pleasure and try to find rational, workable approaches; concentrate on holism; consider POET and transdisciplinary (e.g. cultural, social, psychological, organizational, environmental, political, legal, moral, operational, economic, legacy, etc.) techniques; win the trust of their constituents through intellectual honesty and objectivity (Unfortunately, this is not usually the case in the secular world!); and trust the results of their efforts, at least until they learn more. Self-organization is one of the principal hallmarks of atheists; they believe that collaboration (cooperation and competition) among all protagonists leads to success.

System of systems engineer: Your description is quite self-congratulatory! Actually, I think we operate in much the same way while practicing SoSE, although perhaps with somewhat less emphasis on those attributes you apply.

Facilitator: Although we're on dangerous ground again, I appreciate the somewhat more polite tone. For a moment let's contemplate how far we've come.

\subsection{Summary of perspectives achieved}

Systems thinker: How well does Table 2 summarize your opinions? SE; SoSE; or ESE/CSE, are labels of the right-most three columns. Theism, Agnosticism, and Atheism are labels of the three rows; the left-most column provides rough definitions of each. The $3 \times 3$ matrix formed by the intersection of the rows and right-most columns contains the exponent-coded characterizations of the attributes of the intersecting methods and belief systems.

Complex systems engineer: I couldn't agree more; hope you all agree, too.

Enterprise systems engineer: This is fine with me.

System of systems engineer: I don't know. With more time and effort, I could revise this table considerably, which I may endeavor to do eventually. However, it also seems, to some extent, we're making much ado about nothing.

Systems engineer: Amen. Let's stick to fundamentals and get on with the actual work improving our systems! 
Table 2: Perspectives on systems engineering attributes

\begin{tabular}{|c|c|c|c|c|c|}
\hline \multirow{25}{*}{ 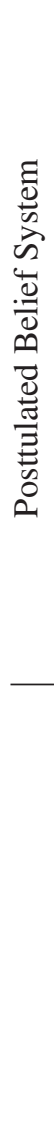 } & Atheism & Rationality & Isolation $^{4}$ & Opportunities $^{1}$ & Holism $^{1}$ \\
\hline & No personal God & Stepticism & Distrust $^{4}$ & Capabilities $^{2}$ & Trans-Disciplines ${ }^{1}$ \\
\hline & No gods at all & Humanism & Contemplation $^{2}$ & Interoperability $^{2}$ & Trust $^{1}$ \\
\hline & & Experimentation & Outreach $^{2}$ & Systems Thinking ${ }^{2}$ & Self-Organization $^{1}$ \\
\hline & & Study & & & \\
\hline & & Synthesis & & & \\
\hline & Agnosticism & Humility & Independence ${ }^{2}$ & $\mathrm{POET}^{1}$ & Humility $^{1}$ \\
\hline & There may be a & Ambivalence & Innovation $^{2}$ & Discussions $^{1}$ & Balance $^{1}$ \\
\hline & God & Uncertainty & Networking $^{2}$ & Heuristics $^{1}$ & Interactions $^{1}$ \\
\hline & Religious & Openness & Science $^{2}$ & Layering $^{1}$ & Simplicity ${ }^{1}$ \\
\hline & Naturalism & Learning Analysis & & & \\
\hline & & Tradition & Risks $^{4}$ & Modularity ${ }^{3}$ & Complication ${ }^{4}$ \\
\hline & Theism & Acceptance & Reductionism 4 & Security $^{3}$ & Optimization $^{4}$ \\
\hline & God exists & Devotion & Technology 4 & Hierarchy ${ }^{3}$ & Point-to-Point ${ }^{4}$ \\
\hline & Pantheism Faith & Faith & Requirements ${ }^{4}$ & Hubris ${ }^{4}$ & Dicta $^{4}$ \\
\hline & & Dogma Ritual & Doctrine $^{4}$ & & \\
\hline & & & SE & SoSE & ESE/CSE \\
\hline & & Systems & Engineering Me & thod & \\
\hline & $\underline{\text { Glossary }}$ & & & Exponent Code & \\
\hline & SE: Classical, Co & entional, or Traditi & onal Systems & 1: CSE Principles & \\
\hline & Engineering & & & 2: Laudable Qualiti & ties \\
\hline & ESE: Enterprise & stems Engineering & & 3: Limitations & \\
\hline & SoSE: System of & ystems Engineering & & 4: Things to Mitiga & \\
\hline & CSE: Complex S & tems Engineering & & & \\
\hline & $\begin{array}{l}\text { POET: Political, } \\
\text { logical [factors] }\end{array}$ & erational, Econom & and Techno- & & \\
\hline
\end{tabular}

Note from Systems Thinker: I applied a code located at the lower right, where an integer exponent is assigned to each attribute, while considering 13 CSE principles from White [3].

Theist: The bottom row this table seems quite reasonable. I've never thought of attributes in such terms.

Agnostic: The middle row is debatable but I'm not yet sure of specific improvements; I'll give that further thought.

Atheist: I have no rational basis for quibbling with the upper row. I'm just happy to be included in this discussion!

Facilitator: So be it for now. Let's now press on to the next topic.

\section{LIFETIME HISTORY OF A SYSTEMS ENGINEER}

Facilitator: I have taken some time and effort to think about key categories of existence that have significant influence in the life of a systems engineer. Bear with me, if you will, and let's consider how these threads might be proportioned. 
3.1 Category definitions and viewpoints of category representatives

Facilitator: I populated five example categories with instance threads:

- Authorities: parents, bosses, project/program leaders/managers, and executives/officials; in business/commerce/industry, and services/government.

- Exposure: family, religion, ethnicity, sports, town/state/country, geography, colleagues, people, nature, travel, events, and politics.

- Learning: elementary/high school, college/university, career, and lifelong.

- Paths: recreation, independent, entertainment, hobbies, relationships, career, investment, and retirement.

- Contributions: accomplishments, artifacts, products, influence, publications, recognition, plaudits, and awards.

I invited representatives of these categories: Boss, Coach, School Teacher, Lover, and Follower, respectively, to join us.

Boss: The dialogue seems academic to me, frankly. What matters is that we get the job done! Someone needs to be in charge/control to direct the effort.

Coach: We need to pay attention to what is important in life as well as work.

School teacher: Lessons taught in school are more enduring than those of the workplace. It comes down to individual effort and following laudable principles.

Lover: Don't miss the fun in life, as the Coach inferred. But all play and no work also makes a dull companion.

Follower: I am intrigued if we are moving toward defining innovative SE techniques. Please remember to share advances and pertinent references with me.

Facilitator: Thanks for your introductory statements. I look forward to more comments. Now let's see how these categories expand/contract as we live.

\subsection{Interpretation of proportions in category threads}

Facilitator: Everyone's lifetime category pattern is unique. Generally, parents dominate early in life, bosses are influential in early career, but gradually the role of authorities diminishes. World exposure and learning start with birth and continues to increase. The number of path choices starts at zero, increases with age, and contracts near end of life. Similarly, value-added contributions start at zero, gradually increase, accelerate during midcareer, and hopefully continue.

School teacher: Everything is based on learning. It's too bad teachers get paid so little when we have so much influence over our future generations.

Conservative advocate: Private/charter schools are the answer, not more government spending on public education.

Liberal supporter: No, private measures are insufficient to establish worldwide leadership in education and technology.

Coach: Exposure to challenges and opportunities, and learning how to mitigate risks through hard-nosed experiences is vital for healthy growth.

Lover: True happiness is dominated by the quality of one's personal relationships.

Follower: Professional relationships count for those without personal companions. 
Systems thinker: Figure 1 illustrates a lifetime (100 years, optimistically) depiction. The vertical bar represents a snapshot of the relative proportions at an arbitrary point (assumed to be between ages 25 and 50). What do you think?

Complex systems engineer: It's uncanny; this could be my own personal profile.

Systems engineer: Roughly speaking, I would interchange the Learning and Exposure threads. In addition, my Paths thread would be significantly narrower.

Facilitator: Okay. Others of you may need more time to assess this. But to save some time for this meeting's end, let's now move to cultural background.

\section{CULTURAL BACKGROUND}

Facilitator: A person's cultural background as shaped by: parents, family, and ethnicity; and religious, occupational, hometown, state, and country environments. Let's next consider the suggestions of how and why all these early factors influence the later life, behavior, and performance a systems engineer.

\subsection{Parents, family, and ethnicity}

Complex systems engineer: Babies and very young children understand complexity, albeit at a rudimentary level. We are born into a world where we have no control and can only explore to survive. One soon recognizes their mother and is expected to speak a language. This process is a profound testament to the power of the mind.

Enterprise systems engineer: I certainly agree with that. To what extent do children retain their facility for grasping and coping with complexities as they get older, or is this innate ability discouraged in school so that it eventually atrophies?

Liberal supporter: Parents have a tremendous influence in shaping their children's lifelong personalities, from ages as young as five, instilling behavior, belief systems, and mores. The extended family also has significant impact.

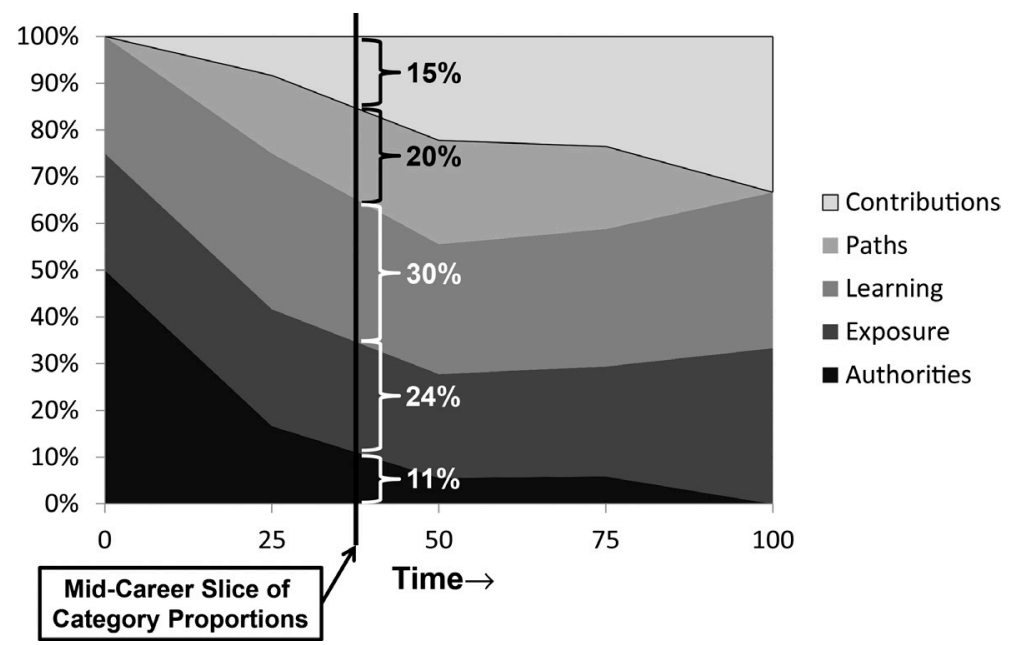

Figure 1: Lifetime proportioning of a systems engineer's existential categories. 
Conservative advocate: The ethnicity of a child's cultural background is also an important factor, since like peoples tend to want to live together. Fortunately, in much of US, Canada, and Europe heterogeneous cultures mitigates this influence.

4.2 Religious, occupational, hometown, state, and country environments

Theist: Religions and occupations practiced by parents are important influences.

Agnostic: A young child cannot make an informed decision about religion, and typically merely accepts what their parents teach. S/he also develops an affinity for mother or father's occupation and wants to become like them.

Atheist: A child begins life as an atheist and quickly becomes a theist due to parental, family, ethnic, and religious environments.

Coach: Most people develop a sense of loyalty to their hometown, their state, and particularly their country. Everyone wants to feel part of the best group.

Follower: One later develops divided loyalties and aligns with other groups. For example, after attending college, starting a career, or getting married.

Parent: This is part of maturing and becoming more independently minded. Many eventually shed much of what they're told but parenting never ceases!

\section{UPBRINGING/EDUCATION}

Facilitator: A child greatly depends on others' guidance. One's response to this influence is critical in shaping further development.

5.1 Fitting into the family mold and teaching right from wrong

School teacher: Parents must teach their children to behave properly. Clearly, such behavior can take many forms based on cultural background.

Parent: Tell me about it! Your job is to motivate kids to learn and to enforce parental instilled discipline while they're in school.

Conservative advocate: If a child does not behave, incentives or disincentives, e.g. a larger allowance or physical punishment, may be applied. Although child-abusive beratements, spankings, or worse, is less prevalent, these practices still exist.

School teacher: Pardon me, again, but another job of parents is to teach children to recognize right from wrong, and to follow a moral path.

Parent: This task we might share and work on together.

Theist: People form their moral outlook, in part, by observing others. The frailties, mistakes, and even immoral actions of someone you like may be overlooked. Similarly, someone you dislike will rarely be emulated.

Conservative advocate: Everyone is dishonest to a degree but, I hope, only in ways that cause no harm. Model the continual pursuit of effective practices.

\subsection{Handling problems and growing socially}

School teacher: The most important job of parents is to expose their children to increasing levels of difficulty, as we do in their schooling. Unfortunately, some parents overprotect their children, and this can make later life much more difficult. 
Parent: Present parties exempted, of course. We might have a parent-teacher meeting on this and other issues in an attempt to see more eye-to-eye.

Complex systems engineer: Children should be taught to understand the problem [4] and ask for advice. One must collaborate in handling difficulties instead of responding in a cavalier, disrespectful, or ineffective manner. Everyone should show appreciation for others' well-intentioned inputs, suggestions, and wisdom.

Parent: Good parents want their children to behave properly in social contexts.

Parent: Sometimes it's important that children be seen and not heard. But a loving absent-childto-relative connection is most welcome. Having frequent family gatherings, especially on holidays, is helpful in guiding children socially.

School teacher: Children learn social behavior with friends. Hopefully, they've already learned the Golden Rule at home while discovering right and wrong.

Parent: There you go again!

Coach: Competitive sports also instill principles of good teamwork.

Liberal supporter: Every person should lead a productive and happy life, making valuable contributions to society that helps others. Fair and worthwhile competition is fine as long as it is unselfish.

Lover: Bring humility to problems and treat everyone with respect.

Facilitator: Thank you, all. Now let's focus a little more education.

\subsection{Elementary/secondary/high school}

Parent: What happens to children in Kindergarten through 12th grade (K-12)? The US is falling behind other countries in education quality. We must stop touting our belief: The US is best in everything! What might we do to improve this situation?

Facilitator: Some of us might volunteer in elementary, secondary, and/or high schools to work with teachers and kids to help instill an appreciation of, and hopefully a love for, STEM (Science, Technology, Engineering, and Mathematics) to bolster college majors in engineering.

Complex systems engineer: In many US elementary schools teachers ask a question and expect kids to provide the one right answer. Consequently, children are desensitized to complexity and are rewarded for oversimplified replies.

School teacher: There is a trend in flipping the classroom, where children are expected to pose the questions based on understanding and curiosity consistent with their original complexity view. This helps preparation for an engineering education.

Systems engineer: Nonetheless, many secondary school students have little interest in science or math. Due to scuttlebutt and peer pressure boys especially fond of these subjects are ridiculed; girls are discouraged and made uncomfortable if they take these supposedly masculine courses.

Coach: Allowing girls to join what have traditionally been boy-only teams helps break down barriers to their participation in technical curricula.

School teacher: Administrators and teachers must do more to motivate STEM pursuits to garner more and better trainees capable of addressing world problems. School-wide recognition of accomplishments in these subjects might help. Happily, there are a growing number of STEM programs.

Atheist: European gymnasiums have enjoyed the reputation of being rigorous and almost university level. Why hasn't the US achieved this? Could it be that our children are coddled, being immersed in their parents' comfortable lifestyle? 
Parent: Our lifestyle is not that comfortable, and we sacrifice for our kids!

Enterprise systems engineer: But again, more must be done in K-12 to lay the groundwork; by high school it is too late.

Systems thinker: The problem is that fundamental.

\section{EXPERIENCE/MATURATION}

Facilitator: We've considered cultural background, and upbringing and education as foundational influences. Professional life begins when one's schooling is over and it's time to get serious. This leads to the last two topics, experience and maturation. So moving right along, let's examine a typical engineering career.

\subsection{Career start and realities}

Systems engineer: A new engineer may not even consider SE, because they are so embroiled in their specialty. Some branch out to cover, explore, or at least dabble in other areas. Lucky ones receive mentoring from a senior colleague, or maybe collectively from fellow employees. A newbie engineer learns to respect the abilities and contributions their colleagues. Self-doubt is an obstacle to overcome until one's own contributions blossom. An engineer quickly learns the rules of the game and assesses the limits of legitimate and approved actions. More aggressive actions can be advocated but prudent management decisions should not be challenged.

Systems thinker: Engineers learn that teams have periods of forming, norming, storming, and performing; continuous high performance is unrealistic.

Boss: Good bosses challenge employees with minimum goals but encourage them to go beyond routine expectations. The grace period associated with new assignments should be reasonable but not too generous.

Follower: A new engineer should be trained to understand a problem through first-hand interactions, a great way to appreciate complex nuances [5]. Experience under several bosses may be invaluable. Leadership/management styles should be observed carefully to form one's own persona or modus operandi.

Boss: There are rules of cultural behavior in an organization, both spoken and unspoken. The new engineer is expected to conform, at least until they prove their worth. Nonconformity may be tolerated if they're good enough technically.

System of systems engineer: An employee who does not conform is likely to be marginalized, demoted, or fired. Choice assignments, good raises, and promotions are strong incentives to conform and perform.

Complex systems engineer: Most SE is embedded in projects or programs run as businesses. The main objectives are obtaining funding, ensuring a profit, and pleasing the customer/sponsor. There are lots of politics. Hopefully, the outcome of the effort will serve a purpose that falls within the public interest. However, many participants are motivated just by technological challenge and recognition for doing well.

Enterprise systems engineer: Watching leaders/managers operate in this environment, and ascertaining what motivates them is enlightening. Many are just looking to keep their nose clean, get a raise or bonus, avoid being demoted, and being able to preserve some personal time. Others build a successful track record, receive higher salaries and promotions, and rise to the top of their organization or pursue enviable assignments elsewhere. 


\subsection{Role models and feelings about work}

Enterprise systems engineer: Most engineers view their boss as a potential role model. Assuming the boss is doing the right kinds of things, s/he will be emulated, and supportive underlings will help make them look good. Otherwise, employees may seek more worthy authorities.

Complex systems engineer: Commendably, a good leader does the right things, even though mistakes are sometimes made. Good managers tend to do things right, and this is fine as long as the right things are being pursued! One may latch onto a mentor and take advantage of their guidance, perhaps following them up the chain of command. Alternatively, one may prefer the challenge of not accepting any special favors from management, and insisting on making the grade alone, speaking truth to power, fighting a broken system, and trying to do the right instead of expedient thing.

Liberal supporter: It's good to think about what has been accomplished. Ask yourself: Is what I'm doing really making a difference, or am I actually part of the problem? One may be working on communications, and not building nuclear weapons, but what if the messages control the delivery of those bombs?!

Systems engineer: Engineers are often classified as antisocial or nerdy. This is consistent with some of their behavior, although engineers typically get along well together. Since systems engineers must interact with others in fulfilling their responsibilities, bosses will appreciate any social skills they exhibit.

Boss: You're right. It's really ideal if I can rely on employees to cooperate collectively in doing what I mandate.

Conservative advocate: What is your reaction when problems arise? Do you deal with them yourself as much as possible? If not, do you try practical fixes as learning experiments and ask for help, as appropriate? If that is unsuccessful, do you go to the boss and complain, or do you bring him/her solutions?

Facilitator: Again, thank you for your participation and stimulating thoughts. Our last meeting topic is maturation.

\subsection{Spiritual and career maturity}

Atheist: If the religion taught to you as a child becomes harder to believe, one might be nudged toward agnosticism. This process might be accelerated after observing lots of people accept horrible events, citing God's will; or, even believing God is all-powerful, blame nature for hurricanes, tsunamis, and earthquakes, etc.

Complex systems engineer: There may be a maturity parallel in thinking about SE. Being taught about SE life cycles with all their accoutrements, and then observing your project/program team following these procedures without success, what does one conclude? Wouldn't one doubt traditional SE and consider other methodologies?

Agnostic: In any event, a process of maturation that establishes spiritual and professional balance in life is usually accomplished by mid-career. Then what?

Lover: Most engineers find out what they're really good at by their 30s or early 40s. These fellas and gals receive suitable recognition for their skills and accomplishments, not only from their bosses but from their colleagues, as well.

Boss: That is not a time to rest on laurels. An engineer should redouble technical efforts to have even more impact. Considerably more latitude in choosing which problems to attack may be afforded to those good enough. 
6.4 Building on career accomplishments

Complex systems engineer: Seeking collective understanding, collaboration, and self-organization are principal tenets of effective engineering-team practice.

Enterprise systems engineer: Sharing information iteratively and bilaterally is crucial for gaining mutual trust. New engineers will find this leads to greater opportunities for collaboration. Unfortunately, many organizations over-protect and withhold highly useful information, and sharing is often punished.

Conservative advocate: So? Information sharing should be done only with permission from the boss.

Boss: Otherwise, it can be too damaging to our efforts. Engineers must be sensitive that any blatant missteps are not too detrimental to recipients. As in any family, this can hurt the parent organization.

Systems engineer: These lessons will be important in a project team in becoming dedicated to solving problems without personally attacking colleagues.

Enterprise systems engineer: Engineers should have considerable latitude in how they do their jobs if they're around awhile; some missteps can be excused

System of systems engineer: Having provided enough technical guidance, engineers need to know when to close the deal, i.e. learn to be good salespeople!

Follower: Late career can be the best time of all. One can review what was learned and accomplished and reapply that wisdom in new contexts.

Lover: Mentoring others is another important activity. One of life's greatest satisfactions is to pass on wisdom acquired through hard work, experience, and a history of honest and trusting relationships.

Enterprise systems engineer: Receiving unexpected, unsolicited compliments from former employees about how they liked working for you is also satisfying.

Complex systems engineer: One never truly fails unless one gives up. Learn from mistakes (made by yourself but preferably others); nothing would get done if nothing was attempted. So take informed risks and pursue opportunities.

System of systems engineer: Resuscitate unfinished work as it better applies.

\section{CONCLUSION}

Facilitator: We have some time remaining for brief comments. Are there any?

Theist: Thanks to much of the discussion, I'm becoming even more of a believer in systems engineering!

Systems engineer: Me, too! Maybe there's more to this than I thought, as well, and I'll cogitate on that while re-thinking from where I came.

Systems thinker: Summarizing, Table 2 offers our perspectives on SE attributes to help a systems engineer characterize her/his approach and performance. One could ask oneself which cells of Table 2 's $3 \times 3$ matrix apply to them and to what relative extent. If a particular cell dominates, is that appropriate? What changes might be made to become more effective as a systems engineer? Similarly, Fig. 1 suggests how several categories of a system engineer's existence are proportioned at each stage of their lives. One could contemplate how these trends have affected their past SE behaviors, and how possible personal re-directions might improve future SE accomplishments.

Complex systems engineer: I think these descriptions fit my career and current mindsight very well. However, I will try not to be judgmental about anyone else's interpretation. Objectively, any chosen way is really no better than any other possibility. As we must realize by now, it all depends 
on a multitude of circumstances in each of our lives. Thinking through what we have done, are doing, and want to do in SE is worthwhile. I recommend such an exercise!

Facilitator: I think these remarks sum things up pretty well. If there are no more comments, I thank you all for participating, and best wishes in solving more of our most difficult problems through improved SE practices.

\section{REFERENCES}

[1] Gorod, A., White, B.E., Ireland, V., Gandhi, S.J., \& Sauser, B.J., Case Studies in System of Systems, Enterprise Systems, and Complex Systems Engineering, CRC Press, Taylor \& Francis Group: Boca Raton, FL, 2015.

[2] Raymo, C., When God is Gone Everything is Holy - The Making of a Religious Naturalist, Sorin Books: Notre Dame, IN, 2008.

[3] White, B. E., Managing uncertainty in dating and other complex systems, Conference on Systems Engineering Research (CSER), 15-16 April 2011, Redondo Beach, CA.

[4] Checkland, P., Systems Thinking, Systems Practice - Soft-Systems Methodology: a 30-year retrospective, Wiley: New York, NY, 1999.

[5] Giuliani, R.W., Leadership, Miramax Books (Hyperion): New York, NY, 2002. 